\title{
Wear behavior of ZrAIN coated cutting tools during turning
}

Lina Rogström, M. P. Johansson-Joesaar, L. Landalv, M. Ahlgren and Magnus Odén

\author{
Linköping University Post Print
}

Tweet

N.B.: When citing this work, cite the original article.

Original Publication:

Lina Rogström, M. P. Johansson-Joesaar, L. Landalv, M. Ahlgren and Magnus Odén, Wear behavior of ZrAlN coated cutting tools during turning, 2015, Surface \&amp; Coatings Technology, (282), , 180-187.

http://dx.doi.org/10.1016/j.surfcoat.2015.10.029

Copyright: Elsevier

http://www.elsevier.com/

Postprint available at: Linköping University Electronic Press

http://urn.kb.se/resolve?urn=urn:nbn:se:liu:diva-123519

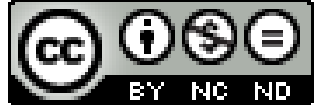




\title{
Wear behavior of ZrAIN coated cutting tools during turning
}

L. Rogström ${ }^{\mathrm{a}}$, M.P. Johansson-Jõesaar ${ }^{\mathrm{a}, \mathrm{b}}$, L. Landälv ${ }^{\mathrm{c}, \mathrm{d}}$, M. Ahlgren ${ }^{\mathrm{d}}$, M. Odén ${ }^{\mathrm{a}}$

${ }^{a}$ Nanostructured Materials, Department of Physics, Chemistry and Biology (IFM), Linköping University, SE-581 83 Linköping, Sweden

bSECO Tools AB, SE-737 82 Fagersta, Sweden

'Thin Film Physics, Department of Physics, Chemistry and Biology (IFM), Linköping University, SE-581 83 Linköping, Sweden

dSandvik Coromant, SE-126 80 Stockholm, Sweden

* Corresponding author: linro@ifm.liu.se, +46 13282955

\begin{abstract}
In this study we explore the cutting performance of ZrAlN coatings. WC:Co cutting inserts coated by cathodic arc evaporated $\mathrm{Zr}_{1-\mathrm{x}} \mathrm{Al}_{\mathrm{x}} \mathrm{N}$ coatings with $\mathrm{x}$ between 0 and 0.83 were tested in a longitudinal turning operation. The progress of wear was studied by optical microscopy and the used inserts were studied by electron microscopy. The cutting performance was correlated to the coating composition and the best performance was found for the coating with highest $\mathrm{Al}$-content consisting of a wurtzite ZrAlN phase which is assigned to its high thermal stability. Material from the work piece was observed to adhere to the inserts during turning and the amount of adhered material and its chemical composition is independent on the Al-content of the coating.
\end{abstract}

Keywords: Zr-Al-N, cathodic arc evaporation, wear, electron microscopy, metal cutting 


\section{Introduction}

Hard and wear resistant coatings are widely used to prolong the tool life in cutting applications. Many of the frequently used physical vapor deposited (PVD) coatings are based on the TiN system, which can be alloyed with for example Al, Si and $\mathrm{Cr}$ to enhance the mechanical properties and the wear resistance [1-7]. One of the most commonly used PVD coating materials is TiAlN, for which the cubic (c) solid solution TiAlN phase decomposes as the coating is exposed to high temperatures, resulting in a fine nanostructure that improves the mechanical properties of the coating [8-10]. Thus, c-TiAlN coated tools typically exhibit good wear resistance $[11,12]$. The formation of wurtzite (w)-AlN phase in many of these materials, e.g. TiAlN and CrAlN, deteriorates the hardness and considerably reduces the wear resistance $[11,13]$. In contrast, the presence of w-AlN in ZrAlN coatings can improve the hardness. [14]. ZrAlN is a much less explored material system, partly due to its large miscibility gap between c-ZrN and c-AlN, which makes it difficult to grow a solid solution of c-ZrAlN, except for low Al-contents [15, 16]. Instead, the ZrAlN coatings have cubic or wurtzite structure depending on Al-content where in both cases the coatings have shown to have high hardness also after being exposed to high temperatures $[14,16-18]$. Recently we reported on the presence of spinodal decomposition in w-ZrAlN coatings, a high temperature behavior which may be favorable for cutting applications [19].

Here, we study the wear of inserts coated with four different ZrAlN coatings by electron microscopy techniques. The results show that the main wear mechanism is abrasive wear of the coating. In addition, plastic deformation of the coating occurs both close to the cutting edge and in the crater region. The higher thermal stability of the wurtzite structure $\mathrm{Zr}_{0.17} \mathrm{Al}_{0.83} \mathrm{~N}$ coating decreases the wear rate compared to the coatings with lower Al-content. The chemical composition of the work piece material that adheres to the tool surface changes with distance from the cutting edge. Both the thickness and the chemical composition of the adhered material is found to be independent on the Al-content of the coating.

\section{Experimental details}

$\mathrm{Zr}_{1-\mathrm{x}} \mathrm{Al}_{\mathrm{x}} \mathrm{N}$ coatings were deposited on WC-10 wt.\% Co inserts (ISO geometry CNMA120412 with a flat rake face) using an Oerlikon Balzers RCS arc-evaporation system. The depositions were performed at a temperature of $400{ }^{\circ} \mathrm{C}$ in a mixed flow of nitrogen and argon at a total pressure of 1.7 Pa. A negative bias of $40 \mathrm{~V}$ was applied to the substrates which were placed on a 3-fold rotation fixture. Four depositions were made using $160 \mathrm{~mm}$ cathodes of $\mathrm{Zr}_{1-\mathrm{x}} \mathrm{Al}_{\mathrm{x}}$ alloys with $\mathrm{x}=0, \mathrm{x}=0.35, \mathrm{x}=0.50$ and $\mathrm{x}=0.83$, respectively. The arc current was $160 \mathrm{~A}, 160 \mathrm{~A}, 150 \mathrm{~A}$, and 120 A for the four cathodes respectively. Before deposition of ZrAlN, the substrates were 
cleaned by Ar ion etching and an approximately $50 \mathrm{~nm}$ thick adhesion layer of TiN was deposited.

The metal cutting performance of ZrAlN coated inserts were tested by using a work piece material of hot rolled and annealed carbon engineering steel, C45E (AISI 1045, 170HB), in a continuous, longitudinal turning operation. The chemical composition of the work piece material is shown in Table I. Cutting tests were performed with cooling, and with a cutting speed $\mathrm{v}_{\mathrm{c}}$ between 220 and $240 \mathrm{~m} / \mathrm{min}$ while the feed and depth of cut were kept constant at $\mathrm{f}=$ $0.2 \mathrm{~mm} / \mathrm{rev}$ and $\mathrm{a}_{\mathrm{p}}=2 \mathrm{~mm}$, respectively. The lower speed was used to produce samples intended for electron microscopy studies, to ensure a longer contact time without complete wear of the coating. In addition to tests made on ZrAlN coated tools, a commercial SECO Tools CP500 TiAlN coating grade was used as reference and tested with the same cutting parameters. Note that this coating grade has an additional TiN top coating of approximately $200 \mathrm{~nm}$. The evolution of tool wear, both flank- and crater wear, was examined with optical microscopy by interrupting, measure and restarting the cutting test every minute. The crater wear is defined as the area of exposed substrate on the rake face and the flank wear as the length of the exposed substrate measured from the edge at the flank side. In addition, electron microscopy samples were prepared using the same cutting parameters for different cutting times in order to study the initial and intermediate stages of wear.

\begin{tabular}{|ccccccccc|}
\hline Element & $\mathbf{C}$ & $\mathbf{M n}$ & $\mathbf{S i}$ & $\mathbf{P}$ & $\mathbf{S}$ & $\mathbf{C u}$ & $\mathbf{C r}$ & $\mathbf{N i}$ \\
Wt\% & 0.43 & 0.79 & 0.227 & 0.012 & 0.022 & 0.03 & 0.06 & 0.02 \\
Element & Mo & $\mathbf{V}$ & Sn & As & $\mathbf{T i}$ & $\mathbf{A l}$ & $\begin{array}{c}\text { Al } \\
\text { met. }\end{array}$ & $\mathbf{N}$ \\
Wt\% & 0.006 & 0.001 & 0.003 & 0.002 & 0.002 & 0.030 & 0.028 & $\begin{array}{c}0.00 \\
52\end{array}$ \\
\hline
\end{tabular}

Table I: Chemical composition of the C45E work piece material where Fe is the balancing element.

The structure of the as-deposited coatings was determined by $\mathrm{x}$-ray diffractometry using $\theta-2 \theta$ geometry and $\mathrm{Cu} \mathrm{K \alpha}$ radiation and a Philips diffractometer. The hardness of the coatings was determined by nanoindentation using a UMIS 2000 system equipped with a Berkovich indenter. 20 indents were made on polished, tapered cross sections ( $8^{\circ}$ tapering angle) of each coating using a maximum load of $50 \mathrm{mN}$. The data was analyzed by the technique of Oliver and Pharr [20] and reported here are the mean value and the standard deviation from the 20 indents. The hardness was measured on as-deposited samples as well as samples annealed in vacuum for 2 h at $900^{\circ} \mathrm{C}$. 
Worn inserts were studied in a scanning electron microscope (SEM) (Zeiss LEO 1550) equipped with an energy dispersive x-ray spectrometer (EDS) (Oxford X-Max). For EDS elemental mapping, an acceleration voltage of $20 \mathrm{kV}$ was used. Fractured cross sections of the as-deposited coatings were studied in the SEM to determine the coating thickness. For selected worn coatings, samples for (scanning) transmission electron microscopy ((S)TEM) studies were prepared by a focused ion beam instrument (FIB) (Zeiss 1540 EsB). The prepared samples were studied in a FEI Technai G2 TF 20 UT microscope operated at $200 \mathrm{kV}$ and equipped with a high angle annular dark field (HAADF) detector for STEM imaging.

\section{$\underline{\text { 3. Results and discussion }}$}

\subsection{Structure and mechanical properties}

Fig. 1 shows $\mathrm{x}$-ray diffractograms of the as-deposited $\mathrm{Zr}_{1-\mathrm{x}} \mathrm{Al}_{\mathrm{x}} \mathrm{N}$ coatings and Table II lists their crystal structure, thickness and mechanical properties. The coatings are labelled according to the cathode composition while the as-measured $\mathrm{Al}$-content is expected to be slightly less due to re-sputtering of Al during growth [21, 22]. The crystal structure, as determined by XRD and confirmed by selected area electron diffraction for the three crystalline coatings, changes from cubic for the $\mathrm{ZrN}$ and the $\mathrm{Zr}_{0.65} \mathrm{Al}_{0.35} \mathrm{~N}$ coatings to wurtzite for the coating containing the largest amount $\mathrm{Al}, \mathrm{Zr}_{0.17} \mathrm{Al}_{0.83} \mathrm{~N}$. These findings are in good agreement with previous studies of ZrAlN coatings $[16,23]$. In the $\mathrm{Zr}_{0.50} \mathrm{Al}_{0.50} \mathrm{~N}$ coating, no diffraction peaks was observed by $\mathrm{XRD}$, which can be expected as ZrAlN coatings with similar composition commonly have a nanocomposite (nc) structure consisting of a mixture of small cubic and hexagonal structured grains and amorphous phases [16, 22].

The thickness of three of the coatings is similar, while $\mathrm{Zr}_{0.50} \mathrm{Al}_{0.50} \mathrm{~N}$ exhibits a lower thickness than the other ZrAlN coatings due to a lower deposition rate. The TiAlN reference coating has a considerable larger thickness than the $\mathrm{Zr}_{1-\mathrm{x}} \mathrm{Al}_{\mathrm{x}} \mathrm{N}$ coatings and is merely used as a reference value of the lifetime of a commercial tool under the present cutting conditions (Section 3.3). The hardness of the ZrAlN coatings varies with Al-content, similar to what was observed in Ref. [16], and the highest hardness is found for the three single phase coatings. For evaluation of the thermal stability of the mechanical properties the hardness was also measured on samples annealed for $2 \mathrm{~h}$ at $900{ }^{\circ} \mathrm{C}$. The highest hardness after annealing is found for the coating with a wurtzite structure, which may be related to the decomposition of this phase at high temperatures $[16,19]$. The elastic modulus derived from the indentation data decreases with $\mathrm{Al}$-content which can be expected as the bulk value of the indentation elastic modulus is higher for c-ZrN (E=460 GPa [24]) than for w-AlN (E=308 GPa [25]). 


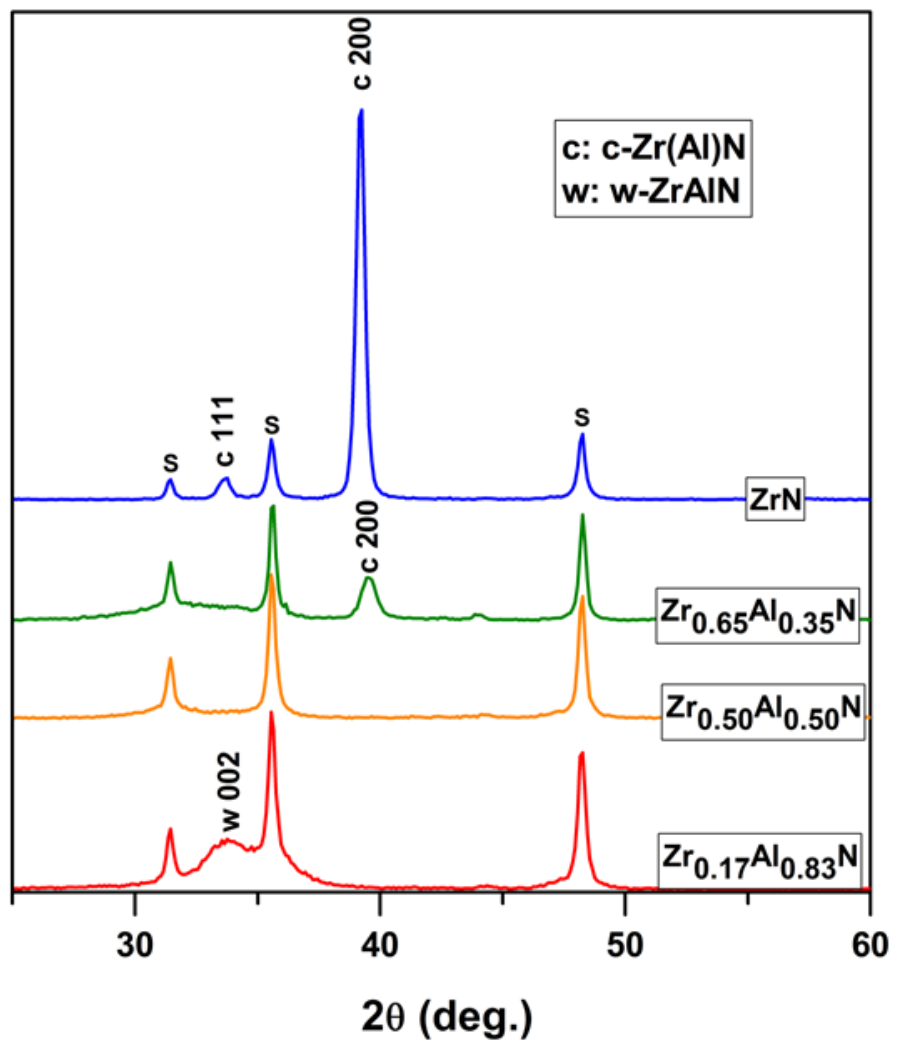

Fig. 1. X-ray diffractograms of the as-deposited $\mathrm{Zr}_{1-\mathrm{x}} \mathrm{Al}_{\mathrm{x}} \mathrm{N}$ coated inserts. $\mathrm{S}$ marks the positions of peaks originating from the substrate.

\begin{tabular}{|lcccccc|}
\hline \multicolumn{1}{|c}{ Coating } & $\begin{array}{c}\text { Crystal } \\
\text { structure }\end{array}$ & $\begin{array}{c}\text { Thickness on } \\
\text { flank side }\end{array}$ & $\begin{array}{c}\text { Thickness } \\
\text { on rake side }\end{array}$ & $\begin{array}{c}\text { Hardness, } \\
\text { as dep. }\end{array}$ & $\begin{array}{c}\text { Elastic } \\
\text { modulus, } \\
\text { as dep. }\end{array}$ & $\begin{array}{c}\text { Hardness, } \\
2 \mathrm{~h} 900{ }^{\circ} \mathrm{C}\end{array}$ \\
& & $(\mu \mathrm{m})$ & $(\mu \mathrm{m})$ & $(\mathrm{GPa})$ & $(\mathrm{GPa})$ & $(\mathrm{GPa})$ \\
$\mathrm{c}-\mathrm{ZrN}$ & $\mathrm{fcc}$ & 2.4 & 2.0 & $26.6 \pm 0.6$ & $529 \pm 18$ & $22.3 \pm 1.1$ \\
$\mathrm{c}-\mathrm{Zr}_{0.65} \mathrm{Al}_{0.35} \mathrm{~N}$ & $\mathrm{fcc}$ & 2.4 & 1.9 & $24.2 \pm 0.5$ & $360 \pm 8$ & - \\
$\mathrm{Zr}_{0.50} \mathrm{Al}_{0.50} \mathrm{~N}$ & nanocrystalline/ & 1.7 & 1.2 & $20.4 \pm 0.6$ & $359 \pm 9$ & $21.8 \pm 1.3$ \\
& amorphous & & & & & \\
$\mathrm{h}-\mathrm{Zr}_{0.17} \mathrm{Al}_{0.83} \mathrm{~N}$ & hexagonal & 2.6 & 2.0 & $23.8 \pm 0.7$ & $293 \pm 6$ & $26.6 \pm 0.7$ \\
$\operatorname{Ti}_{0.33} \mathrm{Al}_{0.67} \mathrm{~N}$ & fcc & 4.0 & & - & - & - \\
$\operatorname{reference}$ & & & & & & \\
\hline
\end{tabular}

Table II: Structure, thickness and mechanical properties of the tested coatings. 


\subsection{Wear and adhered work piece material}

\subsubsection{Wear zones}

Fig. 2 shows optical micrographs of the rake face of worn $\mathrm{Zr}_{1-\mathrm{x}} \mathrm{Al}_{\mathrm{x}} \mathrm{N}$ coated inserts, with increasing Al content $\mathrm{x}$, after turning for 1, 6 and $12 \mathrm{~min}$ at a cutting speed of $\mathrm{v}_{\mathrm{c}}=240 \mathrm{~m} / \mathrm{min}$. The crater wear is evolving with increasing turning time, (from top-to-bottom in Fig. 2). In the case of c- $\mathrm{ZrN}$ and c- $\mathrm{Zr}_{0.65} \mathrm{Al}_{0.35} \mathrm{~N}$ the WC:Co substrate is exposed after 6 min (light gray) while this has not happened even after 12 of turning for the worn $\mathrm{w}-\mathrm{Zr}_{0.17} \mathrm{Al}_{0.83} \mathrm{~N}$ coated insert, which implies an improved crater wear resistance. The thinner nc- $\mathrm{Zr}_{0.50} \mathrm{Al}_{0.50} \mathrm{~N}$ coating was completely worn through already after $7 \mathrm{~min}$. A similar amount of notch wear at the depth of cut (marked with arrows) is apparent in all tested $\mathrm{Zr}_{1-\mathrm{x}} \mathrm{Al}_{\mathrm{x}} \mathrm{N}$ coatings. Notch wear is generally understood as the effect of a strong abrasion between the work hardened machined surface and the cutting tool at the depth of cut.

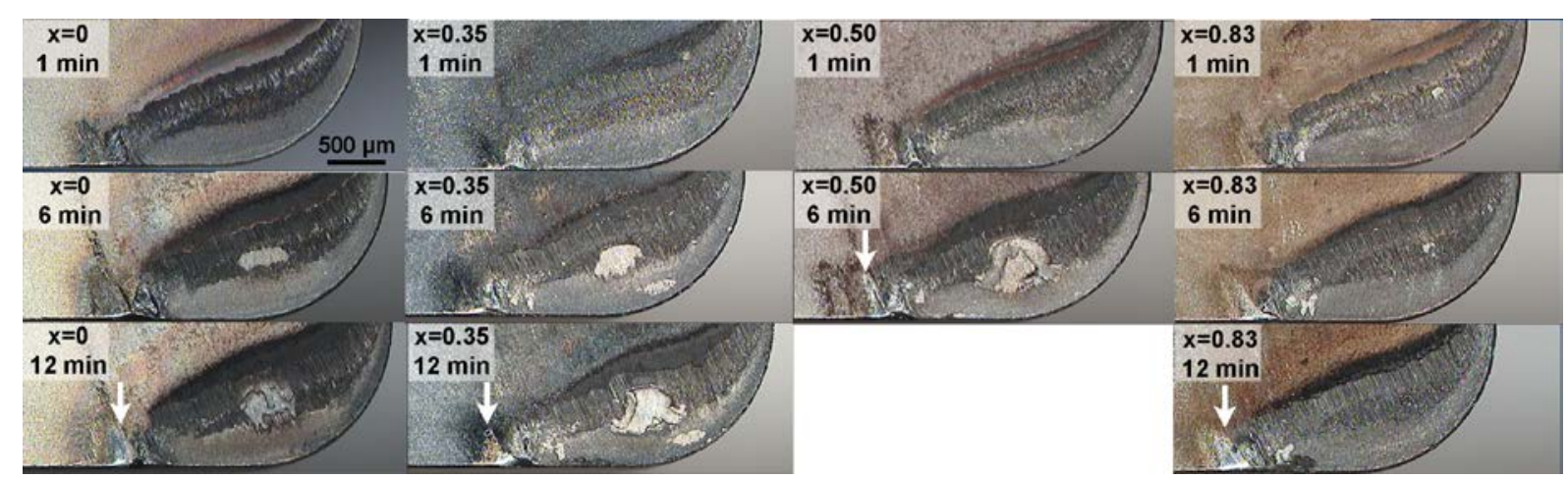

Fig. 2. Optical micrographs showing the rake side of the worn $\mathrm{Zr}_{1-\mathrm{x}} \mathrm{Al}_{\mathrm{x}} \mathrm{N}$ coated inserts, with increasing $\mathrm{Al}$ content $\mathrm{x}$ (left-to-right), operated with $\mathrm{v}_{\mathrm{c}}=240 \mathrm{~m} / \mathrm{min}$ with increasing turning time (top-to-bottom). The arrows mark the notch wear.

Fig. 3a shows a secondary electron SEM micrograph of the rake face (crater wear region) of the c-ZrN coated insert, after 4 min of turning with a cutting speed of $\mathrm{v}_{\mathrm{c}}=220 \mathrm{~m} / \mathrm{min}$. The corresponding wear zones are schematically shown in Fig. 3b. At the position of the arrow, zone I (edge region) stretches from 0-0.3 $\mathrm{mm}$ from the cutting edge, zone II (crater region) between 0.3 and $0.6 \mathrm{~mm}$ from the edge and zone III (chip exit region) from 0.6-0.8 $\mathrm{mm}$ from the edge. In addition, zone IV is in the region of the depth of cut. Similar wear zones were also found on the rake face for all worn inserts in this study. 

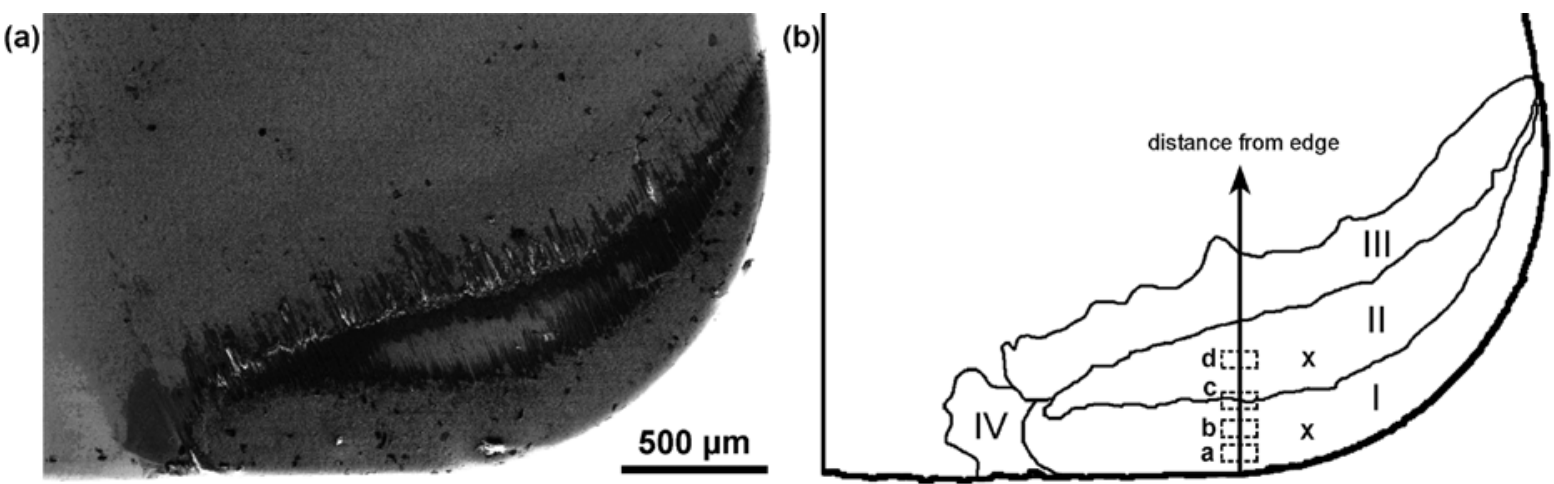

Fig. 3. (a) Secondary electron SEM micrograph of the rake face of the c-ZrN coated insert after 4 min of turning with $\mathrm{v}_{\mathrm{c}}=220 \mathrm{~m} / \mathrm{min}$ and (b) schematic drawing of the wear zones I to IV. The dashed boxes a-d marks the position of where Fig. 5a-d where recorded. $\mathrm{X}$ marks the positions where TEM-samples were prepared (Figs. 5 and 7).

SEM-EDS elemental distribution maps of the adhered layers on the tool surfaces after machining are presented in Fig. 4 for c-ZrN and $\mathrm{w}-\mathrm{Zr}_{0.17} \mathrm{Al}_{0.83} \mathrm{~N}$. These two coatings were selected for further analysis based on their cutting performance, see Section 3.3. The orientation of the tool is the same as in Fig. 3. The elemental maps are recorded after 4 min of turning of a hot rolled steel C45E using a cutting speed of $\mathrm{v}_{\mathrm{C}}=220 \mathrm{~m} / \mathrm{min}$. The cutting time was choosen to aviod substrate exposure in the wear track, i.e. to minimize the effect of the WC:Co in the analysis. W and Co were detected at trace levels only in wear zones I-III. The substrate is, however, exposed at the depth of cut where notch wear (zone IV in Fig. 3b) occurs. The elemental maps for $\mathrm{c}-\mathrm{ZrN}$ and $\mathrm{w}-\mathrm{Zr}_{0.17} \mathrm{Al}_{0.83} \mathrm{~N}$ coatings are comparable to the maps obtained from other $\mathrm{Zr}_{1-\mathrm{x}} \mathrm{Al}_{\mathrm{x}} \mathrm{N}$ coated inserts in this study. Similar maps were also obtained for tests with longer cutting times, except that the WC:Co substrate was exposed in the middle of zone II.

The adhesion of work piece material onto the tool surface show no differences when comparing the $\mathrm{Zr}_{1-\mathrm{x}} \mathrm{Al}_{\mathrm{x}} \mathrm{N}$ coating with different chemical composition and crystal structure, which is consistent with the results of Larsson et al. [26] and Gerth et al. [27].

\subsubsection{Zone I}

In zone I (see Fig. 3b), i.e., the region extending from the cutting edge to approximately half the tool-chip contact length, only small amounts of adhered materials were detected. The adhered material consists of elements from the work piece material, primarily $\mathrm{Al}, \mathrm{Fe}, \mathrm{Mn}$ and S but also small amounts of Mg and Ti. Mn and S are likely in the form of MnS which is a common inclusion in steel. Since this is a soft phase, it is normally found in regions were the abrasive wear is less strong [28] which is also the case here. The $\mathrm{Zr}$-signal, originating from the c-ZrN coating, is observed in this zone as seen in Fig. 4a, suggesting that the thickness of 
the adhered material is less than $1 \mu \mathrm{m}$ (based on the approximate electron interaction depth). Also, a small amount of $\mathrm{O}$ indicates that metal oxides might be present on the tool surface.

(a) $\mathrm{c}-\mathrm{ZrN}$

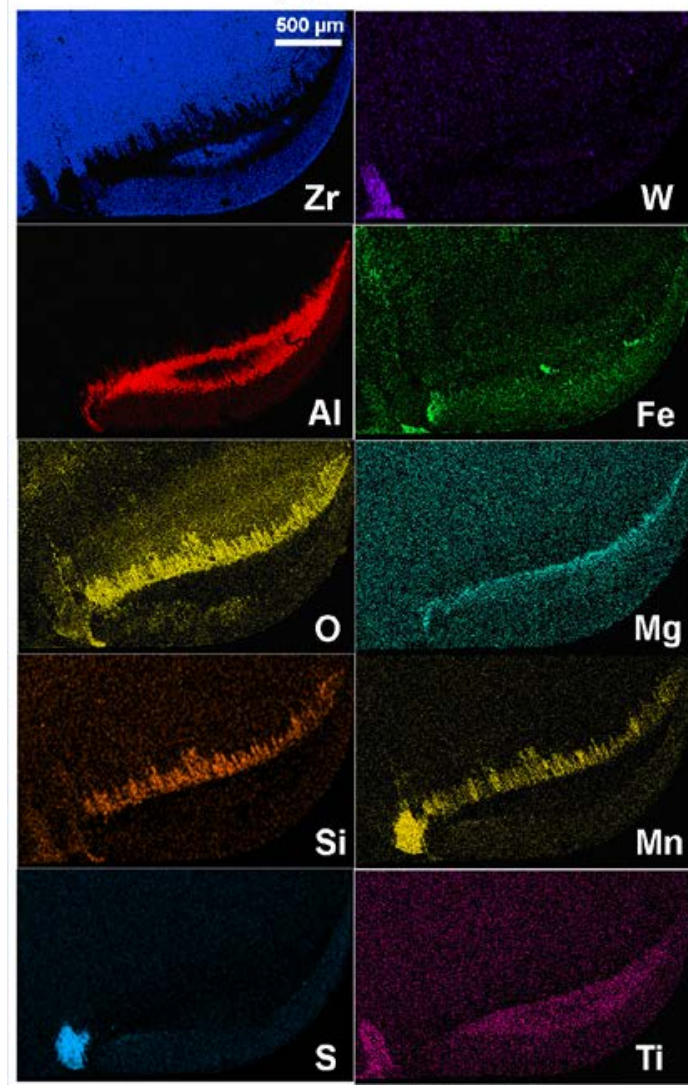

(b) $\mathrm{w}-\mathrm{Zr}_{0.17} \mathrm{Al}_{0.83} \mathrm{~N}$
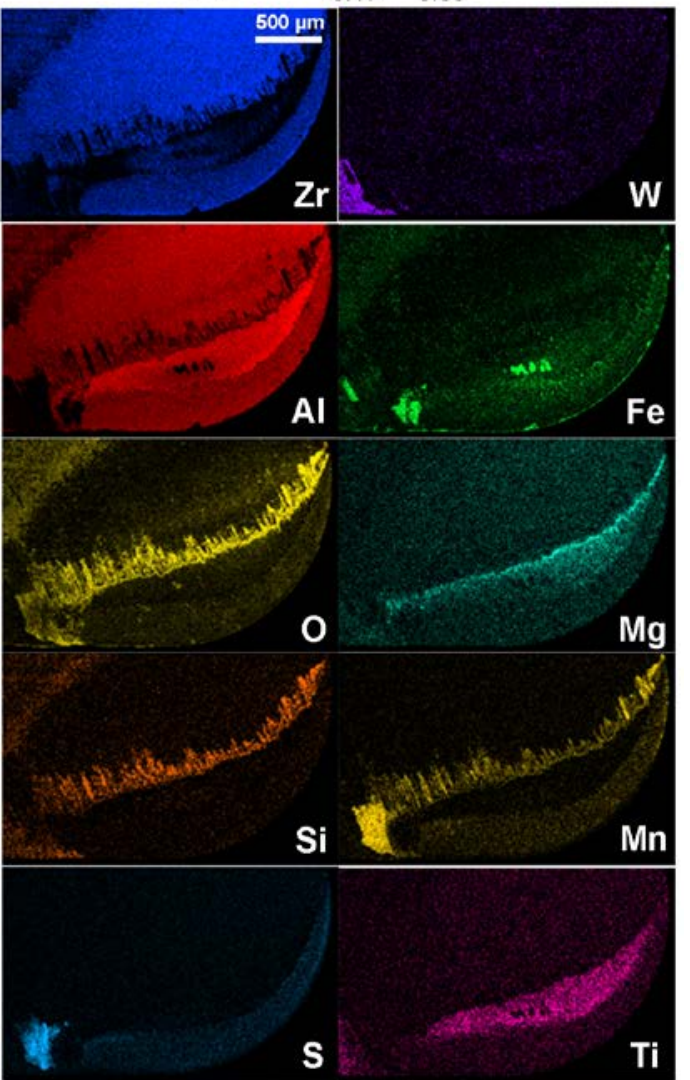

Fig. 4. Elemental distribution maps of selected elements at the rake face of the inserts coated with (a) $\mathrm{c}-\mathrm{ZrN}$ and (b) $\mathrm{h}-\mathrm{Zr}_{0.17} \mathrm{Al}_{0.83} \mathrm{~N}$, after 4 min of turning on hot rolled steel C45E with $\mathrm{v}_{\mathrm{c}}=220 \mathrm{~m} / \mathrm{min}$.

Fig. 5a shows a cross sectional bright field transmission electron micrograph (BF-TEM) of the worn $\mathrm{w}-\mathrm{Zr}_{0.17} \mathrm{Al}_{0.83} \mathrm{~N}$ coated insert after turning for 4 min with $\mathrm{v}_{\mathrm{c}}=220 \mathrm{~m} / \mathrm{min}$ from a sample obtained in zone I (see Fig. 3b). Sever plastic deformation of the coating has occurred with sheared columns in the chip flow direction. This can be expected due to the high temperature and stress at this position of the tool [29, 30], and similar behavior has also been reported for columnar Ti(C,N) coatings [31]. The coating thickness at this specific position varies between 1.5 and $2.0 \mu \mathrm{m}$, indicating that the coating has been worn locally. Sticking of the chip to the tool commonly occurs closest to the cutting edge which means that the part of the chip in contact with the tool is not sliding across the tool surface. Thus, only limited abrasive wear is expected at this location. Fig. 5b shows an elemental contrast STEM micrograph and corresponding EDS elemental maps of the marked area in Fig. 4a. The adhered layer consists of $\mathrm{Fe}, \mathrm{Mn}, \mathrm{Ti}, \mathrm{Al}, \mathrm{S}$ and $\mathrm{O}$ which is consistent with the SEM-EDS results (Fig. 4). Closely matching distributions of S and Mn suggest the presence of a MnS phase. Fe and MnS particles 
are found in the column boundaries of the coating suggesting diffusion of workpiece material into the coating along the column boundaries. The presence of these elements will change the properties of the column boundary and may contribute to the degradation of the coating. Moreover, the oxygen signal is strongest from regions containing $\mathrm{Mn}$ and Fe suggesting the existence of Fe-O and Mn-O phases. Smaller Ti particles are found on the surface of the coating. Finally, a weak $\mathrm{Zr}$ signal is present in the adhered layer, suggesting that coating species diffuses out into the adhered layer.

(a)
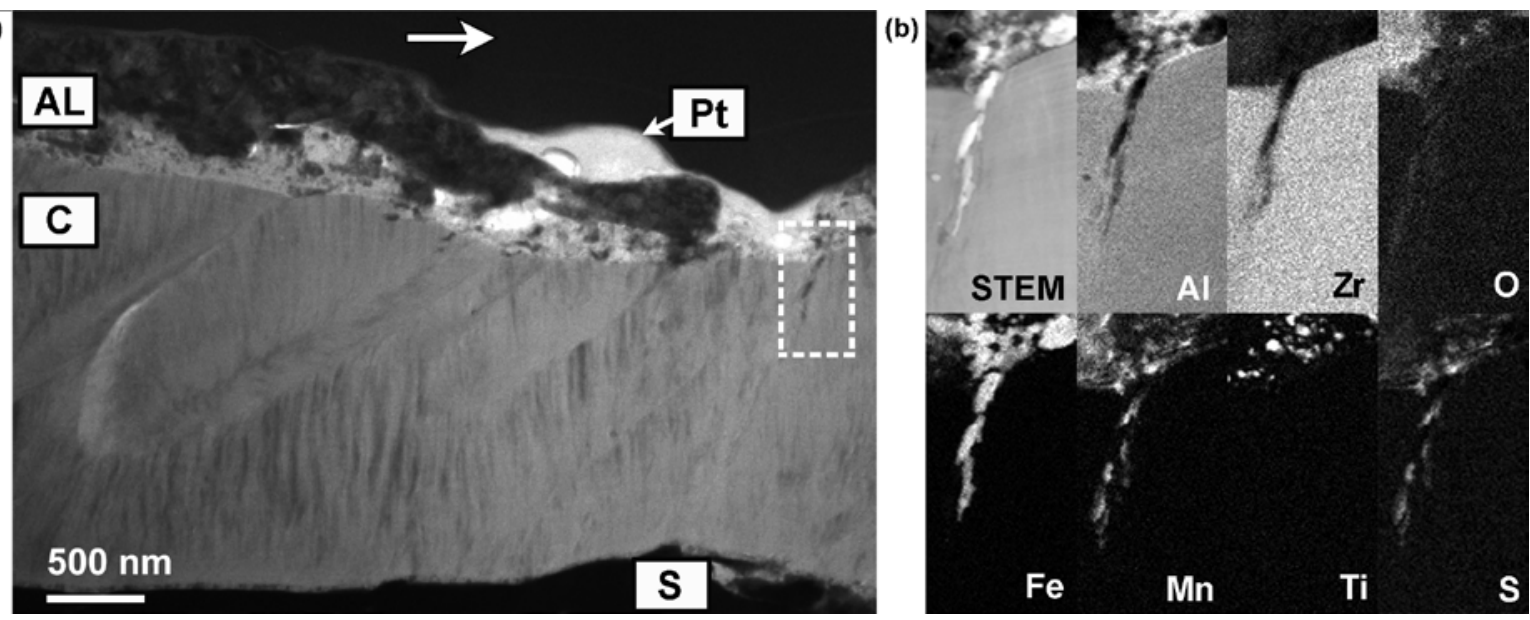

Fig. 5. (a) BF-TEM micrograph of the worn $\mathrm{h}-\mathrm{Zr}_{0.17} \mathrm{Al}_{0.83} \mathrm{~N}$ coated insert after turning for 4 min with $\mathrm{v}_{\mathrm{c}}=220 \mathrm{~m} / \mathrm{min}$ from a sample taken in zone I (see Fig. 3b). Indicated in (a) are the adhered layer (AL), the coating (C), the substrate (S) as well as the Pt-layer (Pt) from sample preparation. (b) shows an elemental contrast STEM micrograph and corresponding elemental maps of the area marked with a dashed rectangle in (a). The white arrow in (a) shows the chip flow direction.

Fig. 6 shows higher magnification secondary electron SEM micrographs of the c-ZrN coated insert after turning for $12 \mathrm{~min}$ with $\mathrm{v}_{\mathrm{c}}=220 \mathrm{~m} / \mathrm{min}$. The micrographs are obtained on the rake face with an increasing distance from the cutting edge, i.e., within zone I to II as schematically shown in Fig. 3b. The rough surface is clearly observed in zone I (Fig. 6a-b). This has been interpreted as the result of a local wear combined with the adherence of MnS, Fe, and $\mathrm{Ti}$ particles identified by EDS (Figs. 4 and 5b). The protruding features increase in size with increasing distance from the cutting edge as shown in Figs. 6a and 6b, respectively. 

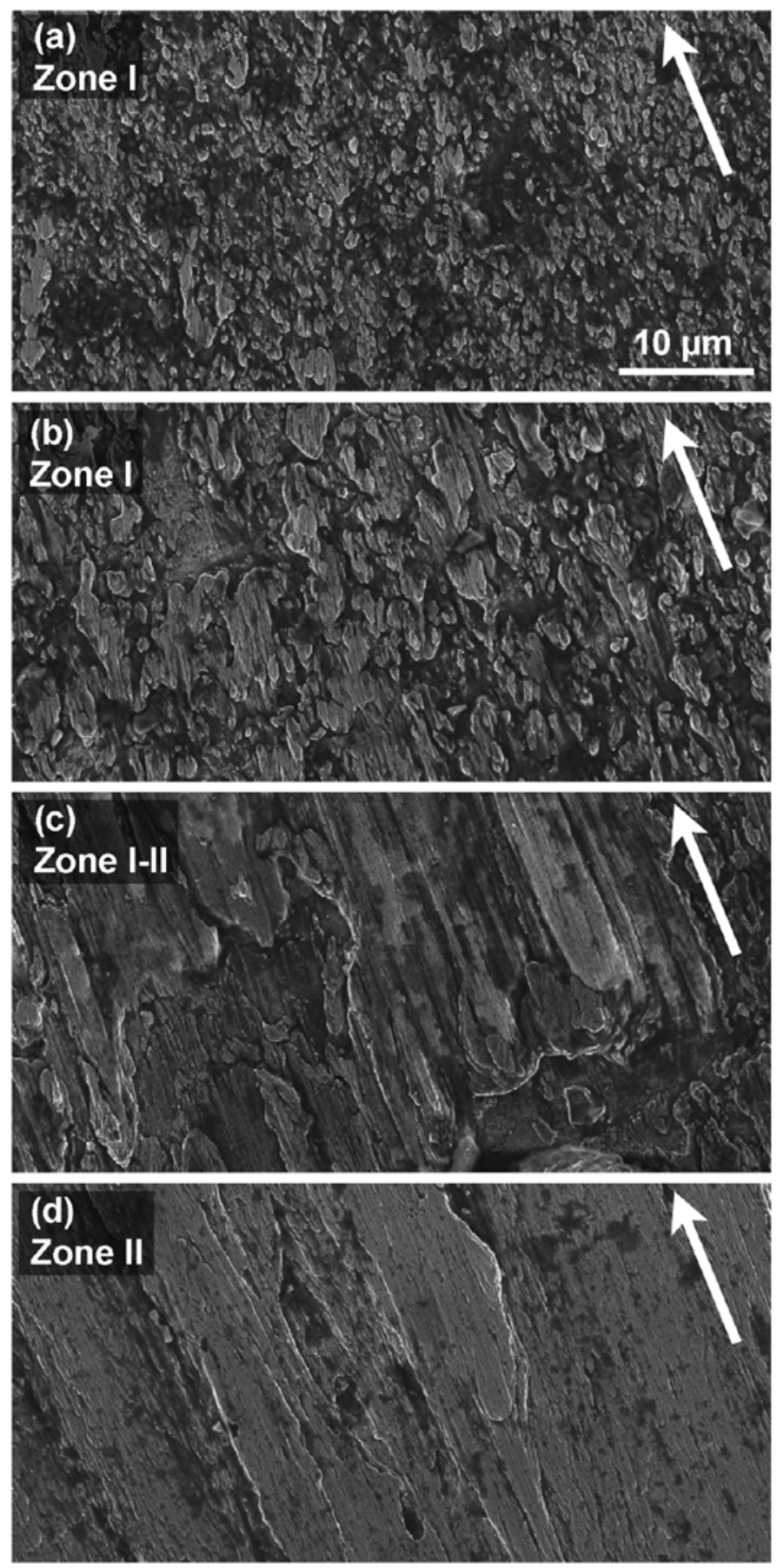

Fig. 6. High magnification SEM micrographs of the c-ZrN coated insert from different regions (a - d) on the rake face (marked in Fig. 3b) after turning for 4 min with $v_{c}=220 \mathrm{~m} / \mathrm{min}$. The arrows show the chip flow direction.

\subsubsection{Zone II}

The largest amount of adhered material is found in zone II. In a large part of zone II, no Zrsignal is recorded from neither the $\mathrm{c}-\mathrm{ZrN}$ nor $\mathrm{w}-\mathrm{Zr}_{0.17} \mathrm{Al}_{0.83} \mathrm{~N}$ coatings (see Fig. 4), i.e. the adhered layer is thicker than the electron interaction depth. In the middle of zone II, however, a Zr-signal originating from the underlying coating is observed suggesting that the adhered layer is thinner in the middle of the zone. The adhered layer mainly consists of Al which is 
evenly smeared across the tool surface. The Al appears to be dominantly metallic since no other element from the EDS analysis correlates with the distribution of $\mathrm{Al}$ on the tool surface. In addition, $\mathrm{Fe}, \mathrm{Ti}$, and small amounts of $\mathrm{Mg}$ are detected in this zone. Ti appears to be evenly distributed in zone II, while Fe is present as larger features, especially in the middle of zone II. The large amount of adhered $\mathrm{Al}$ is not expected from the small amount present in the work piece material, see Table I. Al has a low melting point and can thus be expected to have high diffusivity at the temperatures reached at the tool-chip contact [29, 30]. Similar to the observation made here, large amount of $\mathrm{Al}$ compared to the relative content in the work piece material have also been found in the adhered material during metal cutting elsewhere [27].

The surface changes from protruding features in zone I (Fig. 6a-b) to a smoother surface in zone II (Fig. 6c-d). Fig. 6c shows the adhered Al-rich layer at the boundary between zones I and II. The middle of zone II is observed in Fig. 6d where the amount of adhered material is the thinnest. Here, the surface is smooth while showing wear grooves parallel to the chip flow direction. The smaller amount of $\mathrm{Al}$ (thinner adhesion layer) in this regions is likely due to a combination of high temperature and high tangential forces [29] coupled with a higher material removal rate caused by the strong abrasive wear at this position. This is also the position of the tool where the coating is first worn through to expose the substrate. As apparent from these micrographs, the sliding abrasive wear at the tool-chip contact area is clearly most intense in zone II (crater region) resulting in a smoother surface [32].

Figs. 7a and b show cross-sectional STEM micrographs with elemental contrast of the worn c$\mathrm{ZrN}$ and $\mathrm{w}-\mathrm{Zr}_{0.17} \mathrm{Al}_{0.83} \mathrm{~N}$ coated inserts after turning for $4 \mathrm{~min}$ with $\mathrm{v}_{\mathrm{c}}=220 \mathrm{~m} / \mathrm{min}$, respectively. The images are obtained in zone II (see Fig. 3b). At the top, a Pt protection layer from the FIB sample preparation is observed with bright contrast. Below this is the adhered layer (AL) followed by the coating (C) and the WC:Co substrate (S). The adhered layer has a thickness of about $1 \mu \mathrm{m}$ in the case of c- $\mathrm{ZrN}$ and about $0.5 \mu \mathrm{m}$ for the $\mathrm{w}-\mathrm{Zr}_{0.17} \mathrm{Al}_{0.83} \mathrm{~N}$ coating. Note that the adhered layer thickness is influenced by the position at which the TEM-sample was obtained as the thickness of the adhered layer changes over the crater area, indicated by the varying EDS signal from Zr in the crater area (see Fig. 4) in accord with other observations [33]. For both the worn c- $\mathrm{ZrN}$ and $\mathrm{w}-\mathrm{Zr}_{0.17} \mathrm{Al}_{0.83} \mathrm{~N}$ coated inserts, the top part of the remaining coating is flat and smooth, most likely due to abrasive wear through interface sliding abrasive wear [32] in the tool-chip contact region (crater area), which strongly contributes to the wear of these coatings. Note that both coatings exhibit a columnar structure and some of the columns are tilted in the direction of the chip flow. This is normally observed for columnar structure coatings when exerted to high loads and will eventually lead to fracture of the coating [32]. 
(a)

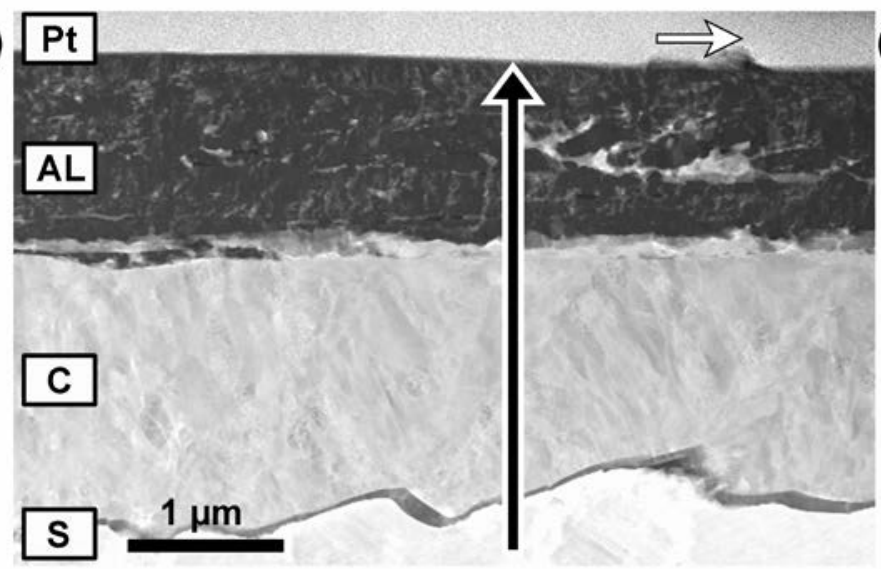

(b)

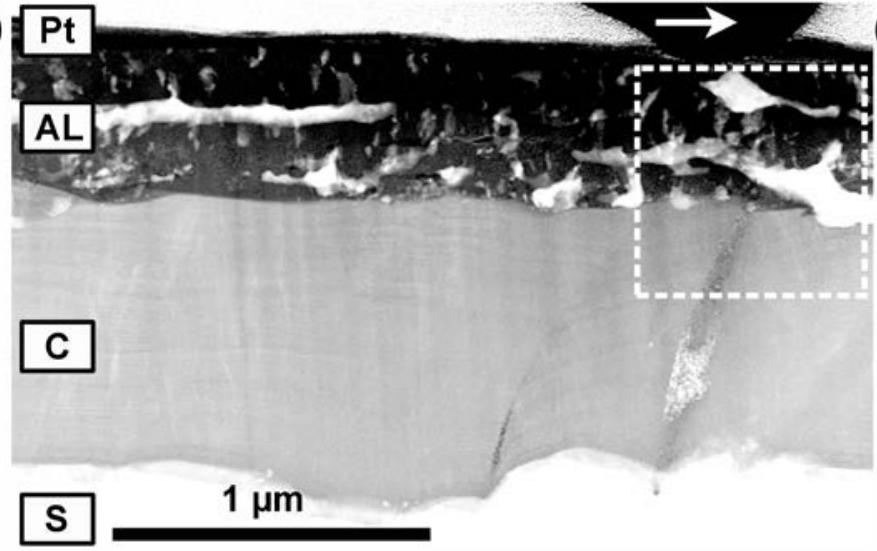

(c)

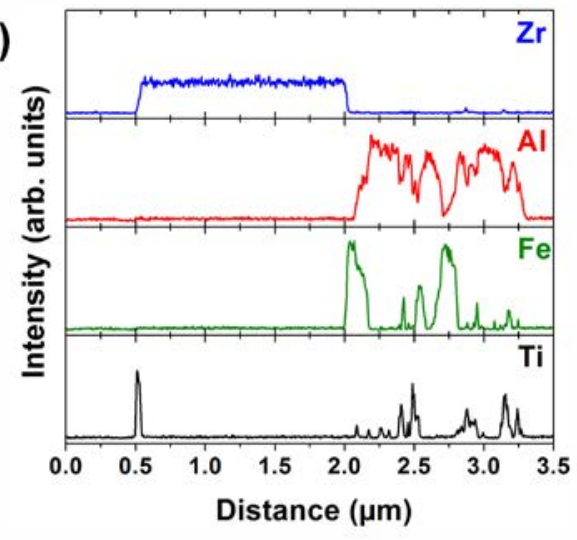

(d)

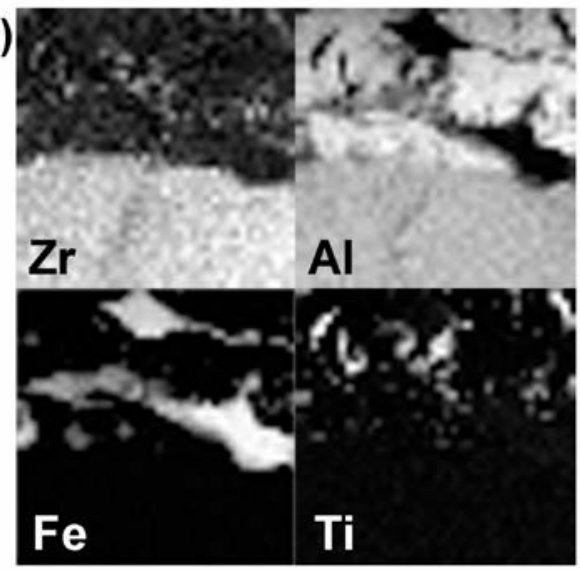

Fig. 7. Elemental contrast STEM micrographs from samples obtained in zone II (see Fig. 3b) after turning for 4 min with $\mathrm{v}_{\mathrm{c}}=220 \mathrm{~m} / \mathrm{min}$ of (a) c-ZrN and (b) $\mathrm{h}-\mathrm{Zr}_{0.17} \mathrm{Al}_{0.83} \mathrm{~N}$ coated inserts. (c) and (d) show an elemental profile and maps, respectively, as indicated by the black arrow and the dashed box in (a) and (b), respectively. The white arrows in (a) and (b) show the chip flow direction.

Fig. 7c shows an EDS line profile starting from the WC:Co substrate, across the worn c-ZrN coating, and over the adhered layer as indicated by the arrow in Fig. 7a. In the adhered layer, larger Fe-particles and smaller Ti-particles are dispersed in a thick $\mathrm{Al}$ layer, consistent with the SEM-EDS results (Fig. 4). No other elements could be detected in the EDS analysis. No Zr originating from the coating is found within the adhered layer. However, wear by dissolution of coating species into the chip cannot be excluded. The Ti-signal at the beginning of the line profile arises from the TiN adhesion layer in between the WC:Co substrate and the c- $\mathrm{ZrN}$ coating. The $\mathrm{Zr}, \mathrm{Al}, \mathrm{Fe}$ and Ti elemental maps in Fig. 7d obtained over the interface region (marked in Fig. 7b) between the worn $\mathrm{w}-\mathrm{Zr}_{0.17} \mathrm{Al}_{0.83} \mathrm{~N}$ coating and corresponding adhesion layer shows a similar elemental structure as the adhered layer of the worn $\mathrm{ZrN}$ coated insert. In both samples, the adhered material has a layered structure with bright contrast Fe particles elongated in the direction of chip flow and dispersed in an Al-matrix. Small amount of $\mathrm{Zr}$ is detected in the adhered layer suggesting out-diffusion of coating species into the adhered layer. Out-diffusion of $\mathrm{Al}$ from the coating cannot be confirmed due to the high Al-content in the adhered layer. 

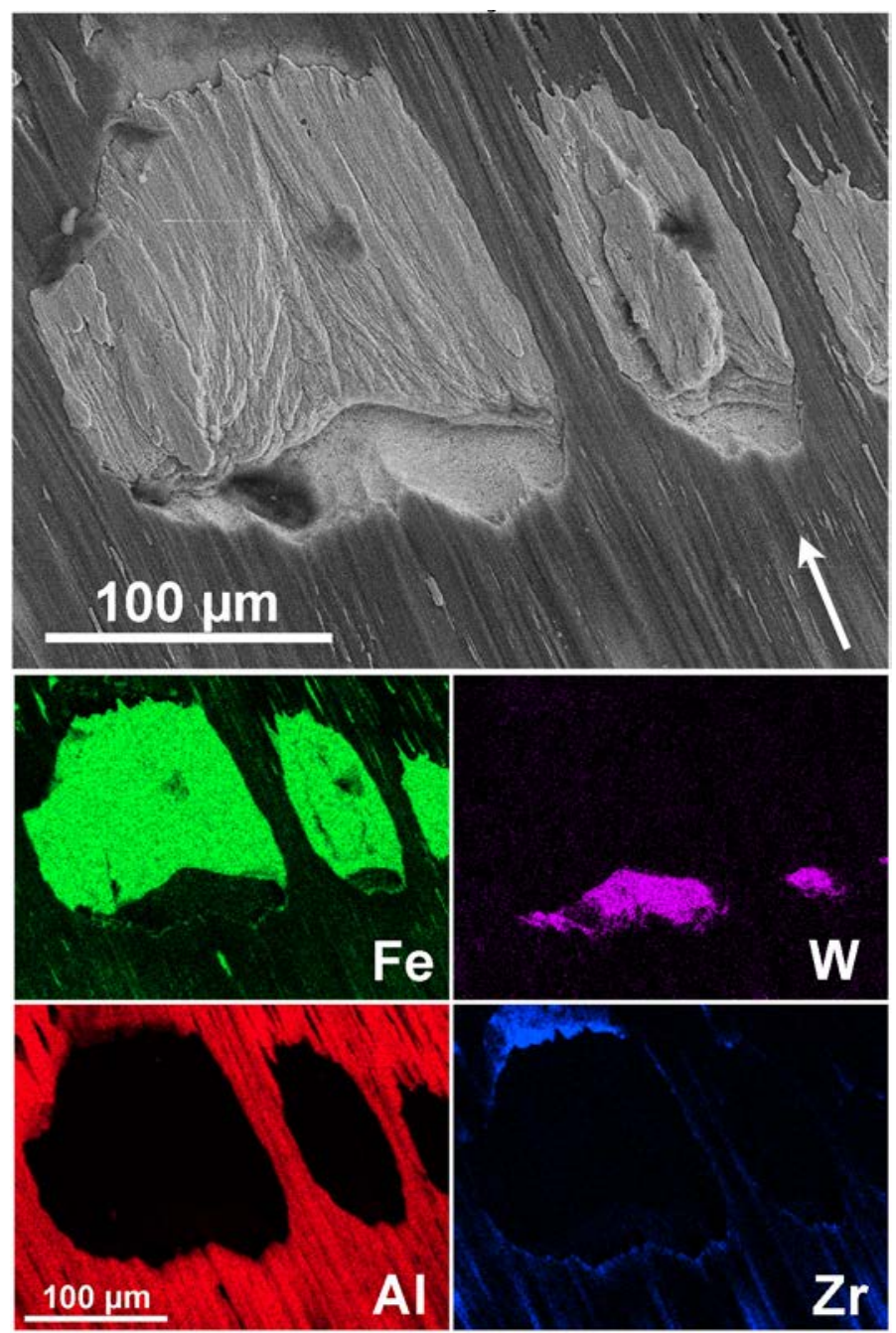

Fig. 8. Secondary electron image and EDS maps of selected elements from the rake face of a c$\mathrm{Zr}_{0.65} \mathrm{Al}_{0.35} \mathrm{~N}$ coated insert after turning for 16 min with $\mathrm{v}_{\mathrm{c}}=220 \mathrm{~m} / \mathrm{min}$. The white arrow shows the chip flow direction.

Fig. 8 shows a SEM micrograph and corresponding EDS maps of the center of zone II of a c$\mathrm{Zr}_{0.65} \mathrm{Al}_{0.35} \mathrm{~N}$ coated insert after extended turning time. At the positions where the coating is worn through and the substrate is exposed, large amount of adhered Fe is observed. This was observed both in zone IV and in the middle of zone II, and suggest that Fe adheres more easily to the WC:Co substrate than to the coatings. This can also be a geometrical effect where Fe particles are scraped off from the work piece at the edge of the crater formed were the coating has been worn off as suggested by Fig. 8. For TiN coatings, it has been observed that edges and holes in the sample surface may act as preferred sites for further adhesion of Fe [34]. Such situation may also promote the adhesion in our case. This would also result in the larger Fe domains observed in Fig. 4. Interestingly, no $\mathrm{Al}$ has adhered on the exposed substrate area, thus the affinity of $\mathrm{Al}$ to the ZrAlN coating is larger than that to the substrate. Surrounding the exposed substrate area, the adhered layer consists mainly of $\mathrm{Al}, \mathrm{Ti}$ and $\mathrm{Mg}$ with a thickness 
that is larger than the electron interaction depth since only a weak $\mathrm{Zr}$-signal originated from the coating is observed.

\subsubsection{Zones III-IV}

Further away from the tool edge, in zone III, the chemical composition of the adhered material mainly consists of Mn, Si and O as observed in Fig. 4. Since the tool surface in this zone is exposed to the atmosphere and only in temporary contact with the chip, the formation of $\mathrm{Mn}$ and Si oxides is probable as these elements are more stable in their oxidized state than their metallic state. Also the amount of $\mathrm{Mg}$ increases with distance from the edge and is largest at the boundary between zone II and III, i.e. at the end of the tool-chip contact length. This might be connected to the low melting point of $\mathrm{Mg}$, resulting in solidification of $\mathrm{Mg}$ where the temperature decreases. Finally, at the depth of cut, in zone IV, mainly Mn, O and Fe are found and hence oxide formation is again likely. The presence of Si at the depth of cut is uncertain and most likely an artefact due to overlap of the Si K $\alpha$ signal with the $\mathrm{W} \mathrm{M} \alpha$ line. The presence of $\mathrm{W}$ from the exposed substrate in this regions is confirmed by other characteristic lines from $\mathrm{W}(\mathrm{L} \alpha)$.

\subsection{Influence of coating composition on wear behavior and cutting performance of the coatings}

Fig. 9 shows crater- and flank wear behavior of the $\mathrm{Zr}_{1-\mathrm{x}} \mathrm{Al}_{\mathrm{x}} \mathrm{N}$ coated inserts as a function of turning time for a hot rolled steel C45E work piece at a cutting speed of $\mathrm{v}_{\mathrm{c}}=240 \mathrm{~m} / \mathrm{min}$. Shown is also the wear of the TiAlN coated insert which here serves as an indication of the wear of a commercial tool under the present cutting conditions. The crater- and flank wear for the $\mathrm{Zr}_{1}$ ${ }_{x} \mathrm{Al}_{\mathrm{x}} \mathrm{N}$ coated inserts show similar trends with the highest wear rate for the $\mathrm{nc}-\mathrm{Zr}_{0.50} \mathrm{Al}_{0.50} \mathrm{~N}$ coating, likely strongly influenced by the lower thickness of this coating (see Table II). The nanocomposite structure of the $\mathrm{nc}-\mathrm{Zr}_{0.50} \mathrm{Al}_{0.50} \mathrm{~N}$ coating also results in a lower hardness than that of the other coatings probably due to more pronounced grain boundary sliding [35] and perhaps even a less dense material [22]. The lowest wear rate is observed for the w$\mathrm{Zr}_{0.17} \mathrm{Al}_{0.83} \mathrm{~N}$ coating. The c-ZrN and $c-\mathrm{Zr}_{0.65} \mathrm{Al}_{0.35} \mathrm{~N}$ coated inserts reveal an intermediate resistance to wear. Similar wear trends were also achieved for the lower cutting speeds used in this study. 
(a)

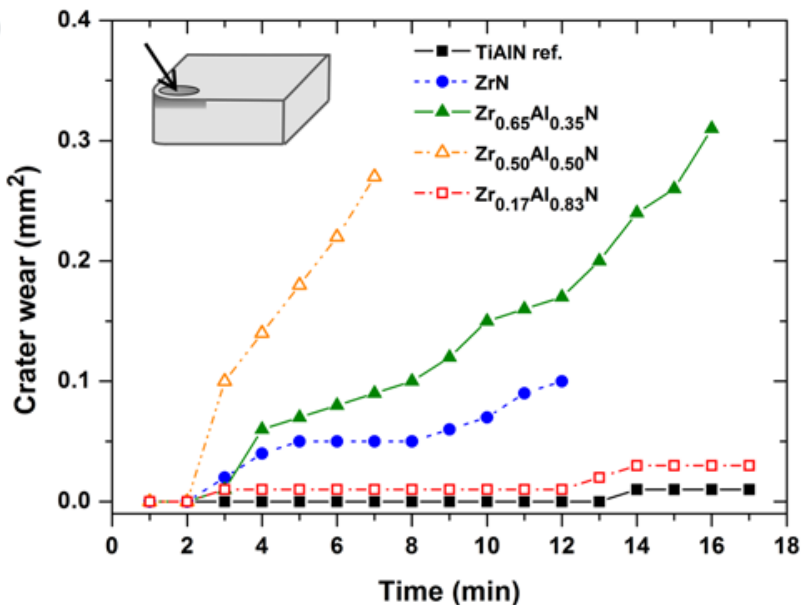

(b)

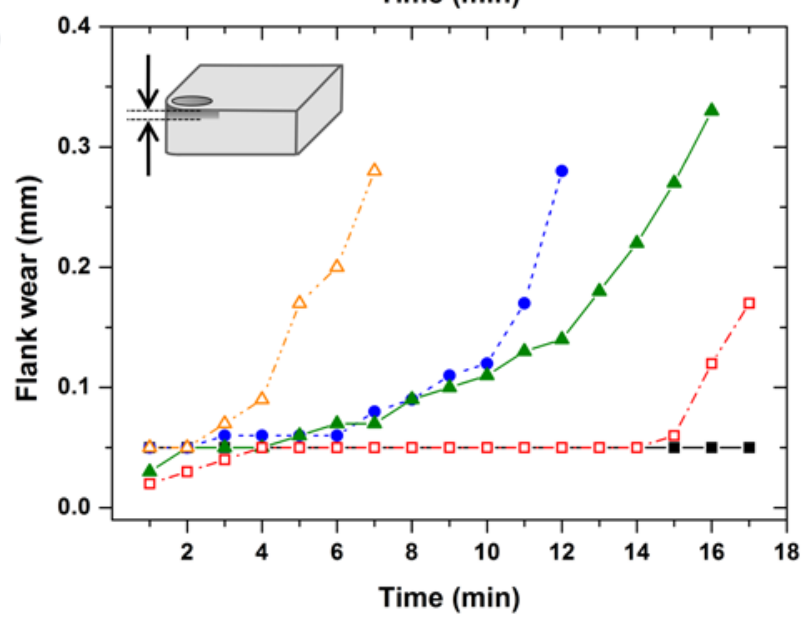

Fig. 9. Crater (a) and flank (b) wear as a function of turning time on hot rolled steel C45E at a cutting speed of $\mathrm{v}_{\mathrm{c}}=240 \mathrm{~m} / \mathrm{min}$.

The large amount of adhered material in the crater region of the tool (zone II) can act as a protective layer, thus decreasing the wear rate. However, since the amount and chemical composition of adhered material is similar for the different coatings, this is not what is causing the difference in cutting performance between the coatings. Thus, the improved wear resistance of the w-ZrAlN coating compared to the lower Al-content coatings must be related to the inherent properties of the coating. One can expect that the higher Al-content coatings have better oxidation resistance, as this has previously been reported for arc evaporated ZrAlN coatings [36]. If an improved oxidation resistance with addition of Al would be directly correlated to the wear rate, the cutting performance of $\mathrm{c}-\mathrm{Zr}_{0.65} \mathrm{Al}_{0.35} \mathrm{~N}$ would be better than that of c-ZrN. Since this is not the case here, we suggest that an improved oxidation resistance with the addition of $\mathrm{Al}$ is not the main contribution to the improved wear resistance of the $\mathrm{w}$ $\mathrm{Zr}_{0.17} \mathrm{Al}_{0.83} \mathrm{~N}$ coating. We note that the hardness of the as-deposited c-ZrN, $\mathrm{c}-\mathrm{Zr}_{0.65} \mathrm{Al}_{0.35} \mathrm{~N}$ and $\mathrm{w}-\mathrm{Zr}_{0.17} \mathrm{Al}_{0.83} \mathrm{~N}$ coatings is similar, which does not reflect their cutting performance. The coating is effectively subjected to a high temperature exposure during a turning operation 
typically around $900^{\circ} \mathrm{C}$ [29]. Therefore one would expect the hardness of the annealed coatings to better correlate with the cutting performance. Previous studies has shown that the w-ZrAlN phase undergoes spinodal decomposition resulting in formation of $\mathrm{ZrN}$ - and $\mathrm{AlN}$ - rich domains within the hexagonal lattice when the coating is exposed to high temperatures $[16,19]$. This results in an increased hardness of the coating [16], thus the increased hardness of the w$\mathrm{Zr}_{0.17} \mathrm{Al}_{0.83} \mathrm{~N}$ after annealing (see Table II) is likely caused by decomposition of the w-ZrAlN phase. The slight increase in hardness upon annealing is in contrast to the other Zr-containing coatings for which the hardness decreases. This is also in line with the results of Franz et al. which found the wear coefficient to be independent of temperature for high Al-content ZrAlN coatings [36]. The behavior of the w-ZrAlN phase is similar to that of c-TiAlN, for which spinodal decomposition of the c-TiAlN phase and the resulting microstructure is responsible for the good wear resistance $[12,37]$. This is however, to our knowledge, the first report on such a behavior for a wurtzite transition metal nitride phase.

\section{Conclusions}

Four arc evaporated ZrAlN coatings were tested in a longitudinal turning operation. The Alcontent in the coating was found to influence the cutting performance where the high $\mathrm{Al}$ content $\mathrm{w}-\mathrm{Zr}_{0.17} \mathrm{Al}_{0.83} \mathrm{~N}$ coating shows the best cutting performance. We suggest that the decomposition of the w-ZrAlN phase is responsible for the higher thermal stability and low wear rate of this coating.

During operation, material adheres to the tool surface and the distribution and chemical composition of the adhered layer is independent on the chemical composition of the ZrAlN coating. Wear of the ZrAlN coatings occurred mainly through abrasive wear in the crater regions while we cannot exclude the effect of chemical wear. In addition, the coating is plastically deformed both close to the cutting edge and in the crater region due to high normal forces and the high temperature.

\section{Acknowledgements}

The VINN Excellence Center on Functional Nanoscale Materials (FunMat) is acknowledged for financial support. 


\section{References}

[1] P.C. Jindal, A.T. Santhanam, U. Schleinkofer, A.F. Shuster, Performance of PVD TiN, TiCN, and TiAlN coated cemented carbide tools in turning, Int. J. Refract. Metal. Hard Mater. 17 (1999) 163.

[2] A. Hörling, L. Hultman, M. Odén, J. Sjölén, L. Karlsson, Thermal stability of arc evaporated high aluminum-content Ti-Al-N thin films, J. Vac. Sci. Technol. A 20 (5) (2002) 1815.

[3] A. Flink, T. Larsson, J. Sjölén, L. Karlsson, L. Hultman, Influence of Si on the microstructure of arc evaporated (Ti,Si)N thin films; evidence for cubic solid solutions and their thermal stability, Surf. Coat. Technol. 200 (2005) 1535.

[4] L. Chen, Y. Du, S.Q. Wang, A.J. Wang, H.H. Xu, Mechanical properties and microstructural evolution of TiN coatings alloyed with Al and Si, Mater. Sci. Eng. A 502 (12) (2009) 139.

[5] L.J.S. Johnson, L. Rogström, M.P. Johansson, M. Odén, L. Hultman, Microstructure evolution and age hardening in $(\mathrm{Ti}, \mathrm{Si})(\mathrm{C}, \mathrm{N})$ thin films deposited by cathodic arc evaporation, Thin Solid Films 519 (2010) 1397.

[6] R. Forsén, M.P. Johansson, M. Odén, N. Ghafoor, Decomposition and phase transformation in TiCrAlN thin coatings, J. Vac. Sci. Technol. A 30 (6) (2012) 061506.

[7] R. Forsén, M.P. Johansson, M. Odén, N. Ghafoor, Effects of Ti alloying of AlCrN coatings on thermal stability and oxidation resistance, Thin Solid Films 534 (0) (2013) 394.

[8] P.H. Mayrhofer, A. Hörling, L. Karlsson, C. Mitterer, L. Hultman, Self-organized nanostructures in the Ti-Al-N system, Appl. Phys. Lett. 83 (10) (2003) 2049.

[9] R. Rachbauer, S. Massl, E. Stergar, D. Holec, D. Kiener, J. Keckes, J. Patscheider, M. Stiefel, H. Leitner, P.H. Mayrhofer, Decomposition pathways in age hardening of Ti-Al-N films, J. Appl. Phys. 110 (2011) 023515.

[10] A. Knutsson, J. Ullbrand, L. Rogström, N. Norrby, L.J.S. Johnson, L. Hultman, J. Almer, M.P. Johansson-Jõesaar, B. Jansson, M. Odén, Microstructure evolution during the isostructural decomposition of TiAlN - A combined in-situ small angle x-ray scattering and phase field study, J. Appl. Phys. 113 (2013) 213518.

[11] A. Hörling, L. Hultman, M. Odén, J. Sjölén, L. Karlsson, Mechanical properties and machining performance of $\mathrm{Ti}_{1-\mathrm{x}} \mathrm{Al}_{\mathrm{x}} \mathrm{N}$-coated cutting tools, Surf. Coat. Technol. 191 (2-3) (2005) 384.

[12] A. Knutsson, M.P. Johansson, L. Karlsson, M. Odén, Machining performance and decomposition of TiAlN/TiN multilayer coated metal cutting inserts, Surf. Coat. Technol. 205 (16) (2011) 4005.

[13] H. Willmann, P.H. Mayrhofer, L. Hultman, C. Mitterer, Hardness evolution of Al-Cr-N coatings under thermal load, J. Mater. Res. 23 (11) (2008) 2880.

[14] N. Ghafoor, L.J.S. Johnson, D.O. Klenov, J. Demeulemeester, P. Desjardins, I. Petrov, L. Hultman, M. Odén, Nanolabyrinthine ZrAlN thin films by self-organization of interwoven single-crystal cubic and hexagonal phases, APL Mater. 1 (2) (2013) 022105.

[15] R. Lamni, R. Sanjinés, M. Parlinska-Wojtan, A. Karimi, F. Lévy, Microstructure and nanohardness properties of Zr-Al-N and Zr-Cr-N thin films, J. Vac. Sci. Technol. A 23 (4) (2005) 593.

[16] L. Rogström, M.P. Johansson, N. Ghafoor, L. Hultman, M. Odén, Influence of chemical composition and deposition conditions on microstructure evolution during annealing of arc evaporated ZrAlN thin films, J. Vac. Sci. Technol. A 30 (3) (2012) 031504.

[17] R. Sanjinés, C.S. Sandu, R. Lamni, F. Lévy, Thermal decomposition of Zr-Al-N thin films deposited by magnetron sputtering, Surf. Coat. Technol. 200 (2006) 6308.

[18] P.H. Mayrhofer, D. Sonnleitner, M. Bartosik, D. Holec, Structural and mechanical evolution of reactively and non-reactively sputtered $\mathrm{Zr}-\mathrm{Al}-\mathrm{N}$ thin films during annealing, Surf. Coat. Technol. 244 (0) (2014) 52. 
[19] L. Rogström, N. Ghafoor, J. Schroeder, N. Schell, J. Birch, M. Ahlgren, M. Odén, Thermal stability of wurtzite $\mathrm{Zr}_{1-\mathrm{x}} \mathrm{Al}_{\mathrm{x}} \mathrm{N}$ coatings studied by in situ high-energy $\mathrm{x}$-ray diffraction during annealing, J. Appl. Phys. 118 (3) (2015) 035309.

[20] W.C. Oliver, G.M. Pharr, An improved technique for determining hardness and elastic modulus using load and displacement sensing indentation experiments, J. Mater. Res. 7 (6) (1992) 1564.

[21] A.O. Eriksson, J.Q. Zhu, N. Ghafoor, M.P. Johansson, J. Sjölén, J. Jensen, M. Odén, L. Hultman, J. Rosén, Layer formation by resputtering in Ti-Si-C hard coatings during large scale cathodic arc deposition, Surf. Coat. Technol. 205 (2011) 3923.

[22] L. Rogström, M. Ahlgren, J. Almer, L. Hultman, M. Odén, Phase transformations in nanocomposite ZrAlN thin films during annealing, J. Mater. Res. 27 (13) (2012) 1716.

[23] H. Hasegawa, M. Kawate, T. Suzuki, Effects of Al contens on microstructures of $\mathrm{Cr}_{1-}$ ${ }_{x} \mathrm{Al}_{\mathrm{x}} \mathrm{N}$ and $\mathrm{Zr}_{1-\mathrm{x}} \mathrm{Al}_{\mathrm{x}} \mathrm{N}$ films synthesized by cathodic arc method, Surf. Coat. Technol. 200 (2005) 2409.

[24] E. Török, A.J. Perry, L. Chollet, W.D. Sproul, Young's modulus of TiN, TiC, ZrN and HfN, Thin Solid Films 153 (1-3) (1987) 37.

[25] D. Gerlich, S.L. Dole, G.A. Slack, Elastic properties of aluminium nitride, J. Phys. Chem. Solids 47 (5) (1986) 437.

[26] A. Larsson, S. Ruppi, Structure and composition of built-up layers on coated tools during turning of Ca-treated steel, Mater. Sci. Eng. A 313 (2001) 160.

[27] J. Gerth, J. Heinrichs, H. Nyberg, M. Larsson, U. Wiklund, Evaluation of an intermittent sliding test for reproducing work material transfer in milling operations, Tribol. Int. 52 (0) (2012) 153.

[28] A. Nordgren, A. Melander, Deformation behavior of different types of inculsion during ship formation in turning of quenched and tempered steels, Mater. Sci. Technol. 5 (1989) 940. [29] N. Norrby, M.P. Johansson, R. M'Saoubi, M. Odén, Pressure and temperature effects on the decomposition of arc evaporated $\mathrm{Ti}_{0.6} \mathrm{Al}_{0.4} \mathrm{~N}$ coatings in continuous turning, Surf. Coat. Technol. 209 (0) (2012) 203.

[30] R. M'Saoubi, H. Chandrasekaran, Investigation of the effects of tool micro-geometry and coating on tool temperature during orthogonal turning of quenched and tempered steel, Int. J. Mach. Tool. Manuf. 44 (2-3) (2004) 213.

[31] S. Ruppi, B. Högrelius, M. Huhtiranta, Wear characteristics of TiC, Ti(C,N), TiN and Al2O3 coatings in the turning of conventional and Ca-treated steels, Int. J. Refract. Metal. Hard Mater. 16 (4-6) (1998) 353.

[32] R. M'Saoubi, M.P. Johansson, J.M. Andersson, Wear mechanisms of PVD-coated PCBN cutting tools, Wear 302 (1-2) (2013) 1219.

[33] R. M'Saoubi, H. Chandrasekaran, Innovative Methods for the Investigation of Tool-Chip Adhesion and Layer Formation during Machining, CIRP Annals - Manuf. Technol. 54 (1) (2005) 59.

[34] U. Wiklund, S. Rubino, K. Kádas, N.V. Skorodumova, O. Eriksson, S. Hedberg, M. Collin, A. Olsson, K. Leifer, Experimental and theoretical studies on stainless steel transfer onto a TiN-coated cutting tool, Acta Mater. 59 (1) (2011) 68.

[35] K. Yalamanchili, R. Forsén, E. Jiménez-Piqué, M.P. Johansson Jöesaar, J.J. Roa, N. Ghafoor, M. Odén, Structure, deformation and fracture of arc evaporated $\mathrm{Zr}-\mathrm{Si}-\mathrm{N}$ hard films, Surf. Coat. Technol. 258 (0) (2014) 1100.

[36] R. Franz, M. Lechthaler, C. Polzer, C. Mitterer, Oxidation behaviour and tribological properties of arc-evaporated ZrAlN hard coatings, Surf. Coat. Technol. 206 (2012) 2337.

[37] M.P. Johansson Jõesaar, N. Norrby, J. Ullbrand, R. M'Saoubi, M. Odén, Anisotropy effects on microstructure and properties in decomposed arc evaporated Ti1-xAlxN coatings during metal cutting, Surf. Coat. Technol. 235 (0) (2013) 181. 